\title{
Implementasi Peraturan Pemerintah Nomor 18 Tahun 2016 tentang Perangkat Daerah pada Penataan Kelembagaan Sekretariat Daerah
}

\section{Implementation of Government Regulation No. 18 of 2016 on Regional Devices on Institutional Arrangement of the Regional Secretariat}

\author{
Susilawaty Munthe ${ }^{1) *}$, Warjio') \& Kariono ${ }^{2)}$ \\ 1) Kantor Pemerintah Daerah Kabupaten Dairi, Sumatra Utara, Indonesia \\ 2)Fakultas Ilmu Sosial dan Ilmu Politik, Universitas Sumatera Utara, Indonesia
}

Abstrak

Penelitian ini bertujuan untuk mengetahui dan menganalisis faktor-faktor yang mempengaruhi dan penghambat dalam pelaksanaan Impelementasi Peraturan Pemerintah Nomor 18 Tahun 2016 tentang Perangkat Daerah pada Penataan Kelembagaan Sekretariat Daerah Kabupaten Dairi. Metode penelitian ini menggunakan metode penelitian deskriptif dengan metode kualitatif. Teknik pengumpulan data melalui, wawancara dilakukan terhadap informan kunci yang dianggap benar-benar dapat memberikan informasi baik mengenai orang, peristiwa atau hal, dengan tidak mementingkan jumlah informan tetapi lebih mementingkan bagaimana relevansinya dan ketepatannya dengan penelitian yang dilakukan. Hasil penelitian memperlihatkan bahwa Implementasi Peraturan Pemerintah Nomor 18 Tahun 2016 tentang Perangkat Daerah Penataan Kelembagaan Sekretariat Daerah Kabupaten Dairi sudah berjalan namun belum optimal. Hal tersebut dapat dilihat dari beberapa aspek. Aspek pertama adalah komunikasi yang memperlihatkan bahwa komunikasi dan koordinasi internal di lingkungan Perangkat Daerah lainnya masih belum berjalan dengan baik. Kedua adalah Sumber Daya memperlihatkan masih belum terpenuhi sesuai dengan jumlah yang dibutuhkan baik secara jumlah maupun kompetensi. Aspek ketiga, adalah Sikap Birokrasi yang memperlihatkan adanya program kegaiatan sehingga perlu pembenahan dan penataan yang tidak. Aspek keempat adalah Standard Operational Prosedure (SOP) dalam melaksanakan impelementasi telah mengacu sesuai tahapan yang telah ditetapkan. Untuk SOP sesuai dengan struktur organisasi yang baru masih dalam proses penyusunan dan perumusan.

Kata Kunci: Implementasi, Pemerintah Daerah, Penataan Kelembagaan.

\section{Abstract}

This study aims to determine and analyze the factors that influence and inhibit the implementation of the implementation of Government Regulation No. 18 of 2016 on the Regional Devices on Institutional Arrangement Regional Secretariat Dairi. This research method using descriptive research method with qualitative method. Data collection techniques through, interviews conducted on key informants who are considered really able to provide good information about people, events or things, with no importance of the number of informants but more concerned with how its relevance and accuracy with research conducted. The result of the research shows that the Implementation of Government Regulation Number 18 Year 2016 on the Regional Device of Institutional Arrangement of Dairi Regency Secretariat has been running but not yet optimal. This can be seen from several aspects. The first aspect is the communication which shows that internal communication and coordination in other regional apparatus are still not running well. The second is that the resources show are still not fulfilled in accordance with the amount needed both in quantity and competence. The third aspect, is the Bureaucracy Attitude which shows the existence of the program so that the need for correction and structuring that is not. The fourth aspect is the Standard Operational Procedure (SOP) in implementing the implementation has been based on the stages. For SOPs in accordance with the new organizational structure is still in the process of drafting and formulation.

Keywords: Implementation, Local Government, Institutional Arrangement.

How to Cite: Munthe, S. Warjio \& Kariono. (2018). Implementasi Peraturan Pemerintah Nomor 18 Tahun 2016 tentang Perangkat Daerah pada Penataan Kelembagaan Sekretariat Daerah. JPPUMA: Jurnal Ilmu Pemerintahan dan Sosial Politik UMA, 6 (1): 38-52.

${ }^{*}$ Corresponding author:

ISSN 2549-166o (Print)

E-mail: 81susilawatymunthe@gmail.com ISSN 2550-1305 (Online) 


\section{PENDAHULUAN}

Menurut Winataputra (2007) kesadaran berkonstitusi secara konseptual diartikan sebagai kualitas Gejolak dan perubahan lingkungan strategi dalam menghadapi globalisasi, sosio-kultural, perubahan politik, perubahan pimpinan, telah menyebabkan perubahan drastis dan mempengaruhi berbagai aspek kehidupan masyarakat di Indonesia. Sistem Pemerintahan Indonesia mengalami perubahan mendasar pada Tahun 1999 yaitu diberlakukannya sistem desentralisasi. Perubahan tata aturan pemerintahan Indonesia pada hakekatnya merupakan upaya dalam penyelenggaraan pemerintahan yang baik atau Good Govermance. Salah satu tujuan Good Govemance adalah mendekatkan pemerintah dengan rakyat. Dengan demikian apa yang menjadi kebutuhan, permasalahan, keinginan, dan kepentingan serta aspirasi masyarakat dapat dipahami secara baik dan benar oleh pemerintah. Sehingga pemerintah mampu menyediakan layanan kepada masyarakat secara efisien, mampu mengurangi biaya, memperbaiki output dan penggunaan sumber daya manusia secara lebih efektif.

Pelaksanaan otonomi daerah memberikan keleluasan bagi pemerintah daerah untuk menyusun organisasi perangkat daerahnya. Dasar utama penyusunan perangkat daerah dalam bentuk suatu organisasi adalah adanya urusan pemerintahan yang menjadi kewenangan daerah, yang terdiri dari urusan wajib dan urusan pilihan, namun tidak berarti bahwa setiap penanganan urusan pemerintahan harus dibentuk kedalam organisasi tersendiri. Dengan perubahan terminologi pembagian urusan pemerintah yang bersifat konkuren berdasarkan Undang-Undang Nomor 23 Tahun 2014 tentang Pemerintahan Daerah, maka dalam implementasi kelembagaan setidaknya terwadahi fungsi-fungsi pemerintahan tersebut masing-masing tingkatan pemerintahan. Pembentukan kelembagaan daerah diatur dalam Undang-Undang Nomor 23 Tahun 2014 pasal 208 yang mengungkapkan bahwa perangkat daerah kabupaten/kota terdiri atas sekretariat daerah, sekretariat DPRD, inspektorat, dinas, badan dan kecamatan.

Dengan terbitnya Undang-Undang Nomor 23 Tahun 2014 tentang Pemerintah Daerah membawa perubahan yang signifikan terhadap pembentukan Perangkat Daerah, yakni dengan prinsip tepat fungsi dan tepat ukuran (rightsizing) berdasarkan beban kerja yang sesuai dengan kondisi nyata di masingmasing Daerah. Hal ini juga sejalan dengan prinsip penataan organisasi perangkat daerah yang rasional, proporsional, efektif dan efisien. Dengan membentuk kelembagaan, maka Pemerintah Daerah dapat menyelenggarakan pemerintahan secara efisien untuk meningkatkan pelayanan dan kesejahteraan masyarakat. Bahwa untuk melaksanakan ketentuan Pasal 232 ayat (1) Undang Undang Nomor 23 Tahun 2014 tentang Pemerintah Daerah. Maka ditetapkanlah Peraturan Pemerintah Republik Indonesia Nomor 18 Tahun 2016 tentangPerangkat Daerah. Setiap 
daerah sesuai dengan karakter daerahnya akan mempunyai prioritas yang berbeda antara satu Daerah dengan Daerah lainnya dalam upaya menyejahterakan masyarakat. Ini merupakan pendekatan yang bersifat asimetris artinya walaupun Daerah sama-sama diberikan otonomi yang seluas-luasnya, namun prioritas Urusan Pemerintahan yang dikerjakan akan berbeda satu Daerah dengan Daerah lainnya. Konsekuensi logis dari pendekatan asimetris tersebut maka Daerah akan mempunyai prioritas Urusan Pemerintahan dan kelembagaan yang berbeda satu dengan lainnya sesuai dengan karakter daerah dan kebutuhan masyarakat.

Pembentukan dan susunan Perangkat Daerah berdasarkan Peraturan tersebut ditetapkan dengan Peraturan Daerah. Peraturan Daerah pembentukan dan susunan perangkat daerah berlaku setelah mendapat persetujuan dari Menteri bagi Perangkat Daerah Provinsi dan dari Gubernur sebagai wakil Pemerintah Pusat bagi perangkat daerah kabupaten/kota. Persetujuan Menteri atau Gubernur sebagai wakil Pemerintah Pusat diberikan berdasarkan pemetaan Urusan Wajib dan Urusan Pemerintahan Pilihan. Menteri atau Gubernur sebagai wakil Pemerintah Pusat menyampaikan jawaban menyetujui seluruhnya atau menyetujui dengan perintah perbaikan Peraturan Daerah kepada gubernur atau bupati/walikota paling lambat 15 (lima belas) hari sejak diterimanya Peraturan Daerah. Dalam hal Menteri atau gubernur sebagai wakil Pemerintah Pusat menyetujui seluruhnya atas Peraturan Daerah dalam lembaran Daerah sesuai dengan ketentuan peraturan perundang-undangan. Apabila dalam waktu 15 (lima belas) hari, Menteri atau gubernur sebagai wakil Pemerintah Pusat tidak memberikan jawaban, Peraturan Daerah dianggap telah mendapat persetujuan.

Dinamika tuntutan masyarakat akan kualitas pelayanan menuntut pemerintah daerah untuk melakukan pemerintahan daerah kelembagaan sehingga bentuk kelembagaan daerah yang dibuat akan lebih efisien. Karakter ini ditunjukkan dengan struktur kelembagaan yang ramping. Kelembagaan yang besar, akan memungkinkan terjadinya overlap implementasi tugas pokok dan fungsi antar organisasi yang ada. Banyaknya keragaman organisasi kelembagaan yang dibangun oleh Pemerintah Daerah menciptakan potensi terjadinya duplikasi pelakasanaan tugas. Kondisi ini menciptakan sulitnya koordinasi pada tatanan implementasi kebijakan publik juga berakibat pada borosnya penggunaan sumber daya. Banyaknya keragaman organisasi yang dibangun juga menciptakan semakin banyak kemungkinan terciptanya garis konflik diantara organisasi kelembagaan itu sendiri. Organisasi pemerintah yang ramping akan menghasilkan kualitas pelayanan masyarakat lebih berkualitas serta memudahkan bagi penerima layanan. Kondisi ini menjadikan kelembagaan yang tidak berbelit-belit serta prosedur pelayanan yang mudah dipahami oleh masyarakat serta memberikan kejelasan dan kepastian hukum bagi masyarakat. 
Peraturan Pemerintah Nomor 18 Tahun 2016 tentang Perangkat Daerah telah ditetapkan pada tanggal 15 Juni 2016 dan diundangkan pada tanggal 19 Juni 2016 yang mencabut dan menyatakan tidak berlaku Peraturan Pemerintah Nomor 41 Tahun 2017 tentang Organisasi Perangkat Daerah. Peraturan Pemerintah Nomor 18 Tahun 2016 tentang Perangkat Daerah menjadi acuan atau pedoman terbaru bagi Pemerintah Daerah baik Provinsi maupun Kabupaten/Kota dalam rangka penataan Kelembagaan Perangkat Daerah untuk pembentukan Organisasi Perangkat Daerah secara efesien, efektif, dan rasional sesuai dengan kebutuhan nyata dan kemampuan Daerah masing-masing serta koordinasi, integrasi, sinkronisasi dan simplikasi serta komunikasi kelembagaan antara Pusat dan Daerah. Dasar utama pembentukan perangkat daerah adalah adanya urusan pemerintah yang diserahkan kepada daerah dan menjadi kewenangan, yang terdiri dari urusan wajib dan urusan pilihan. Urusan wajib dibagi atas urusan wajib yang berkaitan dengan pelayanan dasar, dan urusan wajib yang tidak berkaitan dengan pelayanan dasar penyelenggaraan.

Dalam Peraturan Pemerintah Nomor 18 Tahun 2016 tentang Perangkat Daerah pasal 2 dijelaskan bahwa, pembentukan Perangkat Daerah dilakukan berdasarkan asas: a) Urusan Pemerintahan yang menjadi kewenangan daerah; b) Intensitas Urusan Pemerintahan dan Potensi Daerah; c) Efisiensi; d) Efektivitas; e) Rentang kendali; f) Tata kerja yang jelas; dan g) Fleksibilitas.
Kabupaten Dairi adalah salah satu Kabupaten yang ada di Propinsi Sumatera Utara yang melaksanakan amanah Peraturan Pemerintah Nomor 18 Tahun 2016 tentang Perangkat Daerah. Untuk menyikapi Peraturan Pemerintah dimaksud, Pemerintah Kabupaten Dairi melalui Bagian Organisasi dan Tata Laksana Sekretariat Daerah Kabupaten Dairi telah melakukan tahapan-tahapan diantaranya, pemetaan, penetapan typology, penyusunan Rancangan Peraturan Daerah tentang Organisasi Perangkat Daerah, penyusunan Rancangan Peraturan Bupati tentang uraian tugas pokok dan fungsi, Analisa Jabatan dan Anggaran Belanja Kegiatan.

Sekretariat Daerah Kabupaten Dairi merupakan salah satu organisasi perangkat daerah yang ditetapkan melalui Peraturan Daerah Kabupaten Dairi Nomor 7 Tahun 2016 tentang Pembentukan Organisasi Perangkat Daerah Kabupaten Dairi. Berdasarkan tipe sesuai dengan pasal 30 Peraturan Pemerintah Nomor 18 Tahun 2016 tentang Perangkat Daerah maka Sekretariat Daerah Kabupaten Dairi tergolong tipe A.Tipe A mewadahi pelaksanaan fungsi sekretariat Daerah Kabupaten dengan beban kerja yang besar. Dengan pelaksanaan Peraturan Pemerintah Nomor 18 Tahun 2016 tentang Perangkat Daerah, maka Sekretariat Daerah Kabupaten Dairi terdiri dari 3 (tiga) Asisten, (I) Asisten Pemerintahan dan Kesejahteraan Rakyat membawahi 4 (empat) Bagian yaitu, (1) Bagian Tata Pemerintahan (2) Bagian Kesejahteraan (3) Bagian Hukum (4) Bagian Organisasi dan Tata Laksana, (II) Asisten 
Susilawaty Munthe, Warjio \& Kariono, Implementasi Peraturan Pemerintah Nomor 18

Administrasi Pembangunan membawahi 2 mempunyai program kegiatan (dari (dua) Bagian yaitu, (1) Bagian Perekonomian (2) Bagian Pembangunan, (III) Asisten pengamatan penulis Bagian Humas dan Administrasi Umum membawahi 3 (tiga) Bagian yaitu, (1) Bagian Umum (2) Bagian Perlengkapan (3) Bagian Humas dan Protokol,dan setiap Bagian mempunyai 3 (tiga) subbagian sehingga secara keseluruhan menjadi 27 (dua puluh tujuh) Subbagian.

Dalam proses pelaksanaan tahapan dimaksud terjadi perubahan kelembagaan maupun struktur organisasi di lingkungan Sekretariat Daerah Kabupaten Dairi juga turut mempengaruhi dari berbagai aspek, diantaranya ketatalaksanaan, Sumberdaya Aparatur, standarisasi sarana dan prasarana kerja. Karena ini kebijakan Peraturan Pemerintah tergolong masih baru sehingga pasti dalam mengimplementasikan belum optimal, masih ada kekurangan dan keterbatasan. Terdapat berbagai permasalahan yang dihadapi oleh Pemerintah Kabupaten Dairi terkhusus Sekretariat Daerah Kabupaten Dairi dalam mengimplementasikan Peraturan Pemerintah Nomor 18 Tahun 2016 tentang Perangkat Daerah tersebut. Diantaranya adalah kurangnya koordinasi antara bagian-bagian terkait ketatalaksanaan masih terdapat ketidaksesuaian dan kurang tepatnya tupoksi serta uraian tugas sesuai jabatan yang ada dilingkungan Sekretariat Daerah. Hal ini sangat penting dan berkaitan dengan penyusunan uraian jabatan untuk pemangku jabatan struktural, jabatan fungsional dan jabatan fungsional umum. Namun masih ada subbagian yang tidak Protokol salah satu subbagian yaitu subbagian protokol, dimana sebelumnya subbagian ini tergabung pada Bagian Umum Sekretariat Daerah yaitu subbagian Tata Usaha dan Protokoler.

Selanjutnya ketersediaan sumber daya manusia atau Aparatur Sipil Negara yang masih perlu penambahan (komposisi penempatan staf/jabatan fungsional umum belum merata, terdapat beberapa subbagian dimasing-masing Bagian tidak memiliki staf/jabatan fungsional umum) serta sarana dan prasarana masih sangat perlu dibenahi, dengan bertambahnya 1(satu) Bagian Sekretariat Daerah Kabupaten Dairi yaitu Bagian Perlengkapan Sekretariat Daerah KabupatenDairi, sehingga perlu penambahan sarana dan prasarana), karena fasilitas maupun sarana dan prasarana sangat berperan guna mancapai efektif dan efisiensi dalam pelaksanaan tugas dan fungsi masingmasing guna meningkatkan kinerja.

\section{METODE PENELITIAN}

Defenisi metode penelitian menurut Soehartono (2002) adalah cara atau strategi menyeluruh untuk menemukan atau memperoleh data yang diperlukan. Penelitian ini termasuk ke dalam penelitian deskriptif dengan metode kualitatif.Hal ini sesuai dengan pernyataan Atherton dan Klemmack (Soehartono, 2002) bahwa penelitian deskriptif “....bertujuan untuk memberikan gambaran tentang suatu masyarakat atau 
kelompok orang tertentu atau gambaran tentang suatu gejala atau hubungan antara dua gejala atau lebih". Sebelum menggunakan metode penelitian kualitatif, ada baiknya penulis menjelaskan terlebih dahulu mengenai metode penelitian kualitatif.

Metode penelitian kualitatif adalah metode penelitian yang digunakan untuk meneliti pada kondisi obyek yang alamiah, (sebagai lawannya adalah eksperimen) dimana peneliti adalah sebagai instrument kunci, teknik pengumpulan data dilakukan secara triangulasi (gabungan), analisis data bersifat induktif, dan hasil penelitian kualitatif lebih menekankan makna dari pada generalisasi. (Sugiono, 2008).

Selanjutnya Sugiono (2008) menyatakan bahwa: Dalam penelitian kualitatif suatu realitas atau obyek tidak dapat dilihat secara parsial dan dipecah ke dalam beberapa variabel. Penelitian kualitatif memandang obyek sebagai sesuatu yang dinamis, hasil konstruksi pemikiran, dan utuh (holistic) karena setiap aspek dari obyek itu mempunyai satu kesatuan yang tidak dapat dipisahkan.

Sebelum membahas mengenai pengumpulan data, penulis akan menjelaskan populasi. Akan tetapi dalam penelitian kualitatif tidak menggunakan istilah populasi. Spradley (Sugiyono, 2008) menyebutkan sebagai "social situation" atau situasi sosial yang terdiri atas tiga elemen yaitu: tempat (place), pelaku (actors), dan aktivitas (activity) yang berinteraksi secara sinergis. Sebenarnya obyek penelitian kualitatif bukan semata-mata pada situasi sosial yang terdiri dari tiga elemen tersebut, tetapi juga bisa berupa peristiwa alam, tumbuh-tumbuhan, binatang, kendaraan dan sejenisnya.

Dalam penelitian kualitatif ini nantinya, yang menjadi instrument atau alat penelitian adalah peneliti atau penulis sendiri. Penulis yang bertindak sebagai human instrument, berfungsi menentukan fokus penelitian, memilih informan sebagai sumber data, melakukan pengumpulan data, menilai kualitas data, analisis data, menafsirkan data dan membuat kesimpulan atas temuan dilapangan. Hal tersebut didasari atas pendapat Nasution (Sugiyono, 2008: 60) yang menyatakan bahwa: Dalam penelitian kualitatif, tidak ada pilihan lain dari pada menjadikan manusia sebagai instrument penelitian utama. Alasannya ialah bahwa, segala sesuatunya belum mempunyai bentuk yang pasti. Masalah, fokus penelitian, prosedur penelitian, hipotesis yang digunakan, bahkan hasil yang diharapkan, itu sebelumnya tidak dapat ditentukan secara pasti dan jelas sebelumnya. Segala sesuatu masih perlu dikembangkan sepanjang penelitian itu. Dalam keadaan serba tidak pasti dan tidak jelas itu, tidak ada pilihan lain hanya peneliti itu sendiri sebagai alat satu-satunya yang dapat mencapainya.

Dalam penelitian ini nantinya penulis akan menggunakan data yang bersumber dari observasi partisipatif, wawancara dan studi dokumentasi. Marshall (Sugiyono, 2008: 64) menyatakan bahwa "through observation, the researcher learn about behavior and the meaning attached to those behavior". Melalui 
observasi, peneliti belajar tentang perilaku dan makna dari perilaku tersebut. Sedangkan Seohartono (2002: ha 70) mengatakan bahwa: Dalam observasi partisipan, pengamat ikut serta dalam kegiatan-kegiatan yang dilakukan subjek penelitian, ia tetap waspada untuk mengamati kemunculan tingkah laku tertentu. Sejalan dengan pendapat tersebut, Stainback (Sugiyono, 2008: 65) menyatakan "participant observation, the researcher observes what people do listen to what they say, and participates in their activities". Secara bebas dapat diartikan dalam observasi partisipatif, peneliti mengamati apa yang dikerjakan orang, mendengarkan apa yang mereka ucapkan, dan berpartisipasi dalam aktivitas mereka. Wawancara (interview) adalah pengumpulan data dengan mengajukan pertanyaan secara langsung oleh pewawancara (pengumpul data) kepada responden, dan jawaban-jawaban responden dicatat atau direkam dengan alat perekam (tape recorder). Selanjutnya Esterberg (Sugiyono, 2008; 72) mendefenisikan wawancara sebagai " $a$ meeting of two persons to exchange information and idea through question and responses, resulting in communication and join construction of meaning about a particular topic". (Wawancara merupakan pertemuan dua orang untuk bertukar informasi dan ide melalui tanya jawab, sehingga dapat dikonstruksikan makna dalam suatu topik tertentu). Kemudian Esterberg dalam buku yang sama mengemukakan bahwa "interviewing is at the heart of social research. If you look through almost any sociological journal, you will find that much social research is based on interview, either standardized or more in depth". Maksudnya adalah wawancara merupakan hatinya penelitian sosial. Bila dilihat jurnal dalam ilmu sosial, maka akan ditemui semua penelitian sosial didasarkan pada wawancara, baik standar maupun yang dalam.

Kemudian Esterberg (Sugiyono, 2008: 73) juga mengemukakan beberapa macam wawancara, yaitu wawancara terstruktur, semi terstruktur, dan tidak terstruktur. Wawancara terstruktur digunakan sebagai teknik pengumpulan data, bila peneliti atau pengumpul data telah mengetahui dengan pasti tentang informasi apa yang akan diperoleh. Wawancara semi terstruktur termasuk dalam kategori in-dept interview yang dalam pelaksanaannya lebih bebas jika dibandingkan dengan wawancara tersruktur.Tujuan dari wawancara semi terstruktur adalah untuk menemukan permasalahan secara lebih terbuka di mana pihak yang diajak wawancara diminta pendapat dan ide-idenya. Dalam melakukan wawancara, peneliti perlu mendengarkan secara teliti dan mencatat apa yang dikemukakan oleh informan. Sedangkan wawancara tidak terstruktur adalah wawancara bebas di mana peneliti tidak menggunakan pedoman wawancara yang telah tersusun secara sistematis dan lengkap pengumpulan datanya. Oleh karena itu, dalam penelitian penulis menggunakan wawancara semi terstruktur sebagai sumber data yang utama untuk menarik kesimpulan dengan 
tidak mengenyampingkan hasil pengamatan dan dokumen-dokumen terkait. Penentuan sumber data melalui wawancara akan dilakukan penulis secara purposive, yaitu dipilih dengan pertimbangan dan tujuan tertentu.

\section{HASIL DAN PEMBAHASAN}

Pemerintah Kabupaten Dairi melalui Dewan Perwakilan Rakyat Daerah Kabupaten Dairi telah menetapkan Peraturan Daerah Kabupaten Dairi Nomor 7 Tahun 2016 tentang Pembentukan Organisasi Perangkat Daerah di Lingkungan Pemerintah Kabupaten Dairi dan ditetapkan pada tanggal 18 November 2016. Sebagaimana amanah Peraturan Pemerintah Nomor 18 Tahun 2016 tentang Perangkat Daerah, maka sesuai dengan Pasal 5 Peraturan Daerah Kabupaten Dairi Nomor 7 Tahun 2016 dijelaskan Sekretariat Daerah Kabupaten Dairi sebagai salah satu perangkat daerah adalah satuan kerja yang berada dibawah dan bertanggung jawab kepada Bupati Dairi yang mempunyai tugas pokok dan fungsi untuk menyelenggarakan penyusunan administratif kebijakan dan pengkoodinasian administratif perangkat daerah pelaksanaan tugas perangkat daerah serta pelayanan administratif.

\section{Implementasi Peraturan Pemerintah Nomor 18 Tahun 2016 tentang Perangkat Daerah Penataan Kelembagan Sekretariat Daerah}

Sesuai dengan pernyataan Edward III (19984:1) bahwa tanpa implementasi yang efektif maka keputusan pembuat kebijakan tidak akan berhasil dilaksanakan. Implementasi kebijakan adalah aktivitas yang terlihat setelah dikeluarkan pengarahan yang sah dari suatu kebijakan yang meliputi upaya mengelola input untuk menghasilkan output atau outcomes bagi masyarakat. Implementation problem appoarch yang dikenalkan Edward III (1984: 9-10), mengajukan pendekatan masalah implementasi dengan terlebih dahulu mengemukakan dua pertanyaan pokok, yakni: (i) faktor apa yang mendukung keberhasilan implementasi kebijakan? Dan (ii) faktor apa yang menghambat keberhasilan implementasi kebijakan?. Berdasarkan kedua pertanyaan tersebut dirumuskan empat faktor yang merupakan syarat utama keberhasilan proses implementasi, yakni komunikasi, sumber daya, sikap birokrasi atau pelaksana dan sturktur organisasi, termasuk tata aliran kerja birokrasi. Empat faktor tersebut menjadi kriteria penting dalam implementasi suatu kebijakan.

\section{Komunikasi}

Menurut Edward III, implementasi akan berjalan efektif apabila ukuran-ukuran dan tujuan-tujuan kebijakan dipahami oleh individu-individu yang bertanggungjawab dalam pencapaian tujuan kebijakan. Hal ini menyangkut proses penyampaian informasi, kejelasan informasi dan konsistensi informasi yang disampaikan. Komunikasi adalah perekat organisasi. Implementasi kebijakan dapat berfungsi efektif jika pertama-tama mengetahui apa yang harus dilakukan, sebuah 
kebijakan dan instruksi implementasi harus ditransmisikan kepada personil-personil yang tepat sebelum dilaksanakan. Komunikasi semacam ini harus akurat dan harus dipahami oleh para pelaksana/implementor kebijakan.

Ada tiga hal penting yang dibahas dalam proses komunikasi kebijakan, yakni transmisi, konsistensi, dan kejelasan (calrity). Faktor pertama yang mendukung implementasi kebijakan adalah transmisi. Seorang pejabat yang mengimplementasikan keputusan harus menyadari bahwa suatu keputusan telah dibuat dan suatu perintah untuk pelaksanaanya telah dikeluarkan. Faktor kedua yang mendukung implementasi kebijakan adalah kejelasan, yaitu bahwa petunjuk-petunjuk pelaksanaan kebijakan tidak hanya harus diterima oleh para pelaksana kebijakan, tetapi komunikasi tersebut harus jelas. Faktor ketiga yang mendukung implementasi kebijakan adalah konsistensi, yaitu jika implementasi kebijakan ingin berlangsung efektif, maka perintahperintah pelaksanaan harus konsisten dan jelas. (Winarno, 2002)

Kaitannya dengan pentingnya

komunikasi dalam organisasi publik, paling tidak ada ukuran komunikasi yang efektif menurut Harianja (2006), yakni: “1) terciptanya pemahaman yang sama, 2) mempengaruhi sikap dalam kerja, serta 3) tindakan atau perilaku yang berwujud pada semangat dan motivasi kerja untuk peningkatan organisasi. Berkaitan dengan hal tersebut di atas, agar terselenggaranya implementasi dengan efektif, harus ada komunikasi dengan semua pihak-pihak baik dilakukan dengan secara langsung maupun secara tidak langsung oleh Pihak Pemerintah sebagai Stake Holder. Adapun komunikasi yang terjadi dari bawah ke atas dan atas ke bawah oleh Pemerintah Kabupaten Dairi melalui tim telah melakukan komunikasi ke semua pihak terkait dalam melaksanakan implementasi Peraturan Pemerintah Nomor 18 Tahun 2016 tentang Perangkat Daerah. Namun untuk komunikasi dan koordinasi lintas organisasi perangkat daerah yang lainnya masih kurang berjalan dengan baik.

Sebagiamana hasil wawancara dengan Kepala Bagian Organisasi dan Tata Laksana Sekretariat Daerah Kabupaten Dairi. Terkait dengan Implementasi Peraturan Pemerintah Nomor 18 Tahun 2016, bahwasanya telah dilakukan komunikasi yang berjenjang tentang tahapan, prosedur dan segala sesuatu terkait dengan aturan dimaksud, yaitu Tim Pemerintah Kabupaten Dairi melalui Bagian Organisasi dan Tata Laksana Sekretariat Daerah Kabupaten Dairi dengan Kementrian Dalam Negeri dan Kementrian Pendayagunaan Aparatur Negara Reformasi Birokrasi telah melakukan konsultasi, koordinasi dan komunikasi namun dengan keterbatasan waktu dan anggaran, maka komunikasi dan koordinasi cenderung lebih intens dilakukan dengan Pemerintah Provinsi selaku wakil Pemerintah Pusat. Dengan demikian dapat dipahami komunikasi yang berjenjang secara ekternal telah dilaksanakan dengan baik. Namun komunikasi internal belum berjalan dengan efektif. 
Dan menurut pendapat Asisten mengetahui tindakan apa yang harus Pemerintahan dan Kesejahteraan Rakyat dilakukan dan informasi tentang data Sekretariat Daerah Sebagaimana hasil pendukung kebutuhan kepada peraturan wawancara penulis dengan Kepala Bagian pemerintah dan undang-undang. Kekurangan Organisasi Kabupaten Dairi. Kurangnya informasi dan pengetahuan bagaimana sosialisasi lintas organisasi perangkat daerah melaksanakan kebijakan memiliki konsekuensi dilingkungan Pemerintah Kabupaten Dairi, langsung seperti pelaksana tidak sehingga dengan perubahan stuktur organisasi bertanggungjawab, atau pelaksana tidak ada di pada Sekretariat Daerah Kabupaten Dairi terdapat atau masih banyak Aparatur Sipil Negara di Lingkungan Pemerintah Kabupaten Dairi belum mengetahui perubahan dimaksud.

\section{Sumber Daya (Resources)}

Walaupun isi suatu kebijakan sudah baik dan sudah dikomunikasikan secara jelas dan konsisten, tetapi bila sumber daya kurang memahami dan kurang melaksanakan implementasi dari suatu kebijakan tidak akan berjalan efektif. Sumber Daya meliputi empat komponen yaitu staf yang cukup (jumlah dan mutu), karenanya manusia merupakan sumber daya yang paling penting dalam menjalankan suatu kebijakan. Tanpa sumber daya, kebijakan hanya tinggal dikertas dan menjadi dokumen saja. Selain hal tersebut, dua komponen selanjutnya adalah informasi yang dibutuhkan guna pengambilan keputusan, kewenangan yang cukup guna melaksanakan tugas dan tanggung jawab dan fasilitas yang dibutuhkan dalam pelaksanaan. Di lain pihak, informasi merupakan sumber daya penting bagi pelaksanaan kebijakan. Ada dua bentuk informasi yaitu informasi mengenai begaimana cara menyelesaikan kebijakan dan program serta bagi pelaksana harus tempat kerja sehingga menimbulkan inefisiensi.

Impelementasi kebijakan membutuhkan kepatuhan organisasi dan individu terhadap peraturan pemerintah yang ada. Pihak Pemerintah Kabupaten Dairi telah menetapkan Pembentukan Tim Penyusunan Rancangan Peraturan Daerah tentang Kelembagaan Perangkat Daerah di Lingkungan Pemerintah Kabupaten Dairi. Tim merupakan perumus penyusunan kebijakan dimaksud melalui Surat Keputusan Bupati Dairi Nomor 188.05/442/VII/2016 dan ditetapkan pada tanggal 26 Juli 2016.

Sumber Daya Manusia selaku promotor dan yang paling berperan dalam pelaksanaan setiap kebijakan. Sehubungan dengan pelaksanaan kebijakan Peraturan Pemerintah Nomor 18 Tahun 2016 tentang Perangkat Daerah terkait Sumber Daya Manusia telah memenuhi komposisi dari jumlah dan kompetensi, sehingga pelaksanaan kebijakan sudah berjalan.

$$
\text { Begitu juga dengan Penataan }
$$

Kelembagaan Sekretariat Daerah Kabupaten Dairi bahwa Sumber Daya Manusia (ASN) pada Sekretariat Daerah Kabupaten Dairi telah memenuhi komposisi jabatan dan kompetensi, 
namun untuk staf masih perlu penambahan serta pembinaan sebagaimana fungsi dari Sekertariat Daerah selaku tim perumus kebijakan.

Dan dalam pengisian komposisi jabatan Pemerintah Kabupaten Dairi telah mengacu sesuai dengan ketentuan Undang-Undang Nomor 5 Tahun 2014 tentang Aparatur Sipil Negara. Namun untuk penempatan Jabatan Pimpinan Tinggi Pratama (eselon IIb) pada Sekretariat Daerah Kabupaten Dairi tidak dilaksanakan lelang jabatan. Jabatan tersebut diisi oleh Aparatur Sipil Negara (ASN) yang sudah duduk sebagai Pejabat Eselon II, hanya melakukan Rotasi Jabatan.

Tetapi untuk Organisasi Perangkat Daerah Jabatan Pimpinan Tinggi Pratama yang lain dilaksanakan dengan lelang jabatan sesuai dengan Undang-Undang Nomor 5 Tahun 2014 tentang Aparatur Sipil Negara terutama untuk Organisasi Perangkat Daerah yang baru. Namun untuk Jabatan Administrator (Kepala Bagian pada Sekretariat Daerah Kabupaten Dairi yakni eselon III.A) dan Jabatan Pengawas (Kepala Subbagian yakni eselon IV.A) pada Sekretariat Daerah Kabupaten Dairi belum dilakukan lelang jabatan namun masih hasil keputusan Tim Baperjakat yang telah di tetapkan oleh Bupati Dairi.

Sebagaimana pengamatan penulis untuk jabatan administrator (Kepala Bagian) pada Sekretariat Daerah belum sepenuhnya terpenuhi, salah satu Bagian yakni Bagian Umum Sekretariat Daerah Kabupaten Dairi. Namun untuk jabatan pengawas (eselon IV. A) untuk semua Bagian pada Sekretariat Daerah

Kabupaten Dairi telah terpenuhi sesuai jumlah dan kebutuhan. Selanjutnya untuk fungsional umum (staf) masih belum terpenuhi sesuai kebutuhan dan jumlah. Terdapat beberapa Bagian pada Sekretariat Daerah yang Subbagian tidak memiliki staf. Idealnya setiap Subbagian memiliki seorang staf. Sehingga Kepala Subbagian merangkap seluruh tugas yang ada.

Sebagaimana hasil wawancara penulis dengan Kepala Badan Kepegawaian dan Pengembangan Sumber Daya Manusia Kabupaten Dairi menyatakan...........Secara keseluruhan untuk komposisi jabatan fungsionanl umum (staf) untuk semua Organisasi Perangkat Daerah Kabupaen Dairi memang kurang sesuai jumlah dan kebutuhan seharusnya. Kedepan kita akan mengusulkan kepada Kementrian Pendayagunaan Aparatur Negara dan Reformasi Birokrasi untuk pengadaan maupun penerimaan calon Aparatur Sipil Negara di Pemerintah Kabupaten Dairi.

\section{Sikap Birokrasi}

Menurut Mulyono dalam http://mulyono.staff.uns.ac.id/2009/05/28/ model-implementasi-kebijakan-georgeedward-iii/, salah satu faktor yang mempengaruhi efektivitas implementasi kebijakan adalah sikap implementor. Jika impelementor setuju dengan bagian-bagian isi dari kebijakan maka mereka akan melaksanakan dengan senang hati, tetapi jika pandangan mereka berbeda dengan pembuat 
kebijakan maka proses implementasi akan mengalami banyak masalah.

Ada tiga bentuk sikap dan respon implementor terhadap kebijakan; kesadaran pelaksana, petunjuk dan arahan pelaksana untuk merespon program ke arah penerimaan atau penolakan, dan intensitas dari respon tersebut. Para pelaksana mungkin memahami maksud dan sasaran program namun seringkali mengalami kegagalan dalam melaksanakan program secara tepat karena mereka menolak tujuan yang ada di dalamnya sehingga secara tepat karena mereka menolak tujuan yang ada di dalamnya sehingga secara sembunyi mengalihkan dan menghindari implementasi program. Disamping itu, dukungan para pejabat pelaksana sangat dibutuhkan dalam mencapai sasaran program.

Setelah tim telah melaksanakan tugasnya sesuai dengan tahapan-tahapan yang telah ditetapkan, maka Pemerintah Kabupaten Dairi melalui sidang di Dewan Perwakilan Rakyat Daerah Kabupaten Dairi telah menetapkan Peraturan Daerah Kabupaten Dairi Nomor 7 Tahun 2016 tentang Pembentukan Organisasi Perangkat Daerah Kabupaten Dairi. Sesuai pasal 3 ayat (2) Perda dimaksud pada ayat (1) berlaku setelah mendapat persetujuan dari Menteri bagi Perangkat Daerah provinsi dan dari gubernur sebagai wakil Pemerintah Pusat bagi Perangkat Daerah kabupaten/kota. Selanjutnya pada Pasal 3 ayat (3) Persetujuan Menteri atau Gubernur sebagai wakil Pemerintah Pusat sebagaimana dimaksud pada ayat (2) diberikan berdasarkan pemetaan
Urusan Pemerintahan Wajib dan Urusan Pemerintahan Pilihan. Selanjuntnya ayat (4) Menteri atau gubernur sebagai wakil Pemerintah Pusat menyampaikan jawaban menyetujui seluruhnya atau menyetujui dengan perintah perbaikan Perda kepada gubernur atau bupati/walikota paling lambat 15 (lima belas) Hari sejak diterimnya Perda. Dengan demikian Pemerintah Kabupaten Dairi melalui Bagian Organisasi dan Tata Laksana Sekretariat Daerah mengantar sekaligus berkoordinasi ke Gubernur selaku Pemerintah Provinsi sebagai wakil Pemerintah Pusat untuk mendapat persetujuan dan koreksi, dengan batas waktu 15 (lima belas) hari. Hal ini dibenarkan oleh Asisten Pemerintahan dan Kesejahteraan Rakyat Sekretariat Daerah Kabupaten Dairi. Pada Pasal 6 Peraturan Pemerintah Nomor 18 Tahun 2016 ayat (1) Kriteria tipelogi Perangkat Daerah untuk menentukan tipe Perangkat Daerah berdasarkan hasil pemetaan urusan pemerintahan, dengan variabel: (a) umum dengan bobot $20 \%$ (dua puluh persen); dan (b) teknis dengan bobot $80 \%$ (delapan puluh persen), ayat (2) Kriteria variabel umum sebagaimana dimaksud pada ayat (1) huruf a ditetapkan berdasarkan karakteristik Daerah yang terdiri dari atas indikator: (a) jumlah penduduk; (b) luas wilayah; dan (c) jumlah anggaran pendapat dan belanja Daerah. Dalam Peraturan Daerah Kabupaten Dairi Nomor 7 tersebut dalam pasal 5 disebut Sekretariat Daerah Kabupaten Dairi adalah Tipe A (beban kerja besar). Penetapan tipe A ditetapkan berdasarkan Input Data Variabel Sekretariat 
Daerah Kabupaten Dairi. Penetapan tipe A telah disesuaikan dengan dua faktor yaitu faktor umum dengan indikator jumlah penduduk, luas wilayah dan jumlah APBD selanjutnya faktor subtantif/teknis dengan indikator jumlah kecamatan, jumlah desa/kelurahan dan jumlah perangkat daerah kecuali kecamatan, jumlah kebijakan daerah, jumlah ASN serta jumlah APBD.

\section{Struktur Organisasi}

Struktur birokrasi adalah karakteristik, norma-norma, dan pola-pola hubungan yang terjadi berulang-ulang dalam badan-badan eksekutif yang mempunyai hubungan baik potensial maupun nyata dengan apa yang mereka miliki dalam menjalankan kebijakan. Van Horn dan Van Meter menunjukkan beberapa unsur yang mungkin berpengaruh terhadap suatu organisasi dalam implementasi kebijakan, yaitu: 1) Kompetensi dan ukuran staf suatu badan; sebagaimana telah dibahas sebelumnya, salah satu faktor pendukung terlaksananya impelementasi kebijakan adalah tersedianya sumber daya khususnya manusia untuk mengaplikasikan Peraturan Pemerintah tersebut dalam birokrasi dimana dia bertugas, dan memiliki integritas yang tinggi dalam memegang teguh janji yang dibuatnya dalam Pakta Integritas, ataupun patuh terhadap Peraturan Pemerintah yang telah disampaikan; 2) Tingkat pengawasan hirarki terhadap keputusan-keputusan sub unit dan proses-proses dalam badan pelaksana. Tidak hanya dilaksanakan oleh Badan yang berperan langsung dalam hal pengawasan, tetapi juga oleh pihak masyarakat ikut berperan dalam terselenggaranya Impelementasi Peraturan Pemerintah tersebut. Walaupun Peraturan Pemerintah tersebut tidak sampai ke masyarakat langsung; 3) Sumber-sumber politik suatu organisasi (misalnya dukungan dari pihak anggota legislatif) dengan penetapan Peraturan Daerah Kabupaten Dairi Nomor 7 Tahun 2016 tentang Pembentukan Organisasi Perangkat Daerah; 4) Vitalitas suatu organisasi, atau kemampuan untuk berjalan dan berlangsungnya kegiatan di suatu organisasi sesuai dengan Tugas Pokok dan fungsinya; 5) Tingkat komunikasi "terbuka" yaitu jaringan kerja komunikasi horizontal maupun vertikal secara bebas serta tingkat kebebasan yang secara relatif tinggi dalam komunikasi dengan individu-individu diluar organisasi; 6) Kaitan formal dan informal suatu badan dengan badan pembuat keputusan atau pelaksana keputusan. Bila sumberdaya cukup untuk melaksanakan suatu kebijakan dan para implementor mengetahui apayang harus dilakukan, implementasi masih gagal apabila struktur birokrasi yang ada menghalangi koordinasi yang diperlukan dalam melaksanakan kebijakan. Kebijakan yang kompleks membutuhkan kerjasama banyak orang, serta pemborosan sumberdaya akan mempengaruhi hasil implementasi. Perubahan yang akan dilakukan tentunya akan mempengaruhi individu dan secara umum akan mempengaruhi sistem dalam birokrasi. (George Edward III: Implementing public policy, 1980). 


\section{SIMPULAN}

Penataan kelembagaan maupun pola restrukturisasi birokrasi oleh Pemerintah Daerah guna mewujudkan Good Governance. Sekretariat Daerah Kabupaten Dairi salah satu Organisasi Perangkat Daerah di Kabupaten Dairi telah mengimplementasi Peraturan Pemerintah Nomor 18 Tahun 2016 tentang Perangkat Daerah dengan Penataan Kelembagaan Sekretariat Daerah tetapi belum berjalan dengan baik dilihat dari aspek komunikasi, sumber daya, sikap birokrasi dan struktur organisasi. Faktor yang mempengaruhi/penghambat pelaksanaan Implementasi Peraturan Pemerintah Nomor 18 Tahun 2016 tentang Perangkat Daerah Penataan Kelembagaan Sekretariat Daerah Kabupaten Dairi adalah belum baiknya komunikasi lintas organisasi perangkat daerah di lingkungan Pemerintah Kabupaten Dairi. Selanjutnya keterbatasan Sumber Daya sebagai Tim penyusun Rancangan Peraturan Daerah, dan keterbatasan Sumber Daya Manusia baik dari segi komposisi dan kompetensi sebagai implementor atau pelaksanaan kebijakan dimaksud. Dan untuk SOP masih dalam proses karena masih meyesuaikan dengan struktur yang baru sesuai dengan amanat Peraturan Pemerintah Nomor 28 Tahun 2016 tentang Perangkat Daerah.

\section{DAFTAR PUSTAKA}

Aisyah, D. (2003). Hubungan Birokrasi dengan Birokrasi, USU Digital Library, Diakses tanggal 30 November 2008.

Alfian \& Syamsyuddin, N. (1991). Profil Budaya Politik Indonesia, Pustaka Utama Grafit, Jakarta.
Baedhowi. (2004) Implementasi Kebijakan Otonomi Daerah Bidang Pendidikan;Study Kasus di Kabupaten Kendal dan Kota Surakarta. Disertasi Departemen Ilmu Administrasi FISIP UI, Jakarta.

Edward III, G.C. (1980). Implementing Public Polyci, Congressional Quarterly Press, Washington.

Grindle, Merilee S, George C, 1984, Public Policy Implementing, Jai Pressline, London-England.

Hardijto, D. (1995). Teori Organisasi dan Teknik Pengorganisasian, Raja Grafindo Persada.

Jones, C.O. (1970). An Introduction To The Study of Public Policy, Wadsworth, Belmont, CA.

Kadir, A. (2015). Study Pemerintahan Daerah dan Pelayanan Publik, CV. Dharma Persada Dharmasraya.

Marpaung, H.W. (2011). Implementasi Peraturan Daerah Kabupaten Labuhanbatu Nomor 37 Tahun 2008 Tentang Pembentukan Organisasi Dan Tata Kerja Kecamatan, Jurnal Administrasi Publik, 1 (1): 29-50

Mazmanian, D.H. \& Sabatier, P.A. (1983), 1983, Implementation and Public Policy, New York, Harper Collins.

Nasution. (1998). Metode Naturalistik Kualitatif, Tarsito, Bandung.

Nugroho, R. (2004). Kebijakan Publik, Formulasi, Implementasi, dan Evaluasi. Elex Media Komputindo, Jakarta.

Peraturan Bupati Dairi Nomor 20 Tahun 2016 tentang Kedudukan, Susunan Organisasi, Tugas dan Fungsi serta Tata Kerja Perangkat Daerah Kabupaten Dairi.

Peraturan Daerah Kabupaten Dairi Nomor 7 Tahun 2016 tentang Pembentukan Organisasi Perangkat Daerah.

Peraturan Pemerintah Nomor 18 Tahun 2016 tentang Perangkat Daerah.

Rambe, T. (2015). Implementasi Peraturan Daerah Rokan Hilir No.8 Tahun 2009 Tentang Pembangunan Kawasan Kepenghuluan Ujung Tanjung Kabupaten Rokan Hilir, Jurnal Administrasi Publik Universitas Medan Area, 3 (2): 155-160

Sastroatmodjo, S. (1995). Partisipasi Politik, IKIP Semarang Press, Semarang.

Sedarmayanti. (2000). Sumber Daya Manusia dan Produktivitas Kerja, Mandar Maju, Bandung.

Siagian, S. (1995). Teori Pengembangan Organisasi. Bumi Aksara: Jakarta.

Sinambela, L.P. dkk. (2006). Reformasi Pelayanan Publik, Teori Kebijakan, dan Implementasi, Bumi Aksara, Jakarta.

Solichin, A.W. (1997). Evaluasi Kebijakan Publik, PeneSrbit FIA UNIBRAW dan IKIP Malang.

Sugiyono. (2008). Memahami Penelitian Kualitatif, Alfabeta, Bandung.

Suryono, A. (2003) Budaya Birokrasi Pelayanan Publik, Diakses tanggal 30 November 2008. 
Susilawaty Munthe, Warjio \& Kariono, Implementasi Peraturan Pemerintah Nomor 18

Sutarto. (2002). Dasar-Dasar Organisasi, Gadjah Mada University Press,Yogjakarta.

Tarigan, A. (2000). Implementasi Kebijakan Jaring Pengaman Sosial; Studi Kasus Program Pengembangan Kecamatan di Kabupaten Dati II Lebak, Jawa Barat, Tesis Magister Administrasi Publik UGM Yogyakarta.

Turnip, K. (2016). Prokontra dan Resistensi ITC/EGov Perspektif Psikologi Birokrasi, Elmatera Yogjakarta

Undang-Undang Nomor 23 Tahun 2014 tentang Pemerintahan Daerah.
Wibawa, S. (1994). Evaluasi Kebijakan Publik, Jakarta. Raja Grafindo Perkasa.

Widodo, J. (2001). Good Governance: Telaah dari Dimensi Akuntabilitas dan Kontrol Birokrasi pada Era Desentralisasi dan Otonomi Daerah, Insan Cendekia, Jakarta.

Winarni. (2004). Manajemen Perubahan (Management og Change), Prenada Media, Jakarta.

Winarno, B. (2002). Teori dan Proses Kebijakan Publik. Media Pressindo, Yogjakarta. 